\title{
КОГНИТИВНЫЕ И ПСИХОЛОГИЧЕСКИЕ АСПЕКТЫ РАССЕЯННОГО СКЛЕРОЗА
}

\author{
Г.А.Дущанова, Э.Т.Зулфикарова*, С.А.Чумаков \\ Южно-Казахстанская государственная фармацевтическая академия, г.Шымкент, Казахстан
}

Рассеянный склероз заболевание, поражающее людей молодого возраста и приводящее к инвалидизации. Было обследовано 20 больных с рассеянным склерозом на базе кафедры неврологии психиатрии и психологии Южно Казахстанской Государственной Фармацевтической Академии. С целью выявления когнитивных нарушений и психологических аспектов. Во всех группах больных рассеянным склерозом отмечаются когнетивные нарушения, дефицит отмечался в 74,8\% случаев. Когнитивный дефицит при рассеянном склерозе характеризуется нарушением скорости обработки информации, кратковременной памяти, концентрации внимания, исполнительных функций, речи, в менышей степени нарушением зрительно-пространственных способностей. Когнитивные нарушения при рассеянным склерозе носят прогрессирующий характер. Прогрессирование отмечается преимущественно за счёт нарастания выраженности дизрегуляторных и нейродинамических расстройств.

$\mathrm{P}$ ассеянный склероз (РС) - воспалительное демиелинизирующее заболевание ЦНС, возникающее в результате развития аутоиммунных реакций к белкам миелина, характеризуется демиелинизацией и аксональным повреждением нейронов разной степени $[7,9,15,16,17]$.

Это заболевание, поражающее людей молодого возраста и во многих случаях приводящее к инвалидизации, продолжает оставаться проблемой со многими нерешенными вопросами. Это касается не только происхождения и сущности болезни, но и ее клиники, которая, казалось бы, изучена с достаточной полнотой [3, 16, 19].

Высокая актуальность изучения РС обусловлена его значительной распространенностью среди болезней центральной нервной системы. По данным ВОЗ среди неврологических заболеваний РС является наиболее распространенной причиной стойкой нетрудоспособности у молодых людей. В настоящее время в мире насчитывается более 2,5 миллионов больных рассеянным склерозом, в том числе в России около 200 тысяч. Проведенные в последнее время на разных территориях страны эпидемиологические исследования по единой методологии показали, что большинство регионов России относятся к зоне со средней частотой РС (30 - 70 случаев на 100000 населения) [4]. Установлено увеличение распространенности болезни, так если в 1999 году она составляла 26, то в 2003 г. - 31 на 100000 населения [1]. Заболеваемость РС из года в год увеличивается на большинстве территорий. Это связано, прежде всего, с истинным увеличением числа больных и продолжительности их жизни, а также с совершенствованием

*e-mail: ellichka.zh@mail.ru методов ранней диагностики заболевания [4].

В настоящее время известно, что патогенез РС складывается из комплекса иммунопатологических и патохимических реакций $[2,7,9,14$, $15,20,22,24]$. Основным патологическим процессом, характеризующим РС, является воспалительная демиелинизация, которая в одних случаях ограничивается репаративными процессами, включая ремиелинизацию, а в других случаях становится необратимой, приводя к деструкции ткани [22]. Различное сочетание деструктивных (воспаление, демиелинизация, аксональное повреждение) и репаративных (ремиелинизация) механизмов характерно для всех стадий РС. Соотношение между этими процессами различное в разных очагах и в разное время. Подобная гетерогенность, вероятно, имеется и в "нормально выглядящем" белом веществе. Указанная неоднородность морфологических изменений находит отражение в различных клинических проявлениях РС [19].

Многие исследователи также считают, что морфологическим изменениям подвергаются аксоны уже на ранних стадиях РС $[6,11,18]$. Потеря аксонов определяет необратимость процесса как у больных с вторично-прогрессирующим, так и с ремитирующим (РРC) типом течения РС. Однако при прогрессирующем РС отмечаются большее повреждение аксонов и меньшая ремиелинизация, чем при ремиттирующем РС [12].

Когнитивные функций является одним из наиболее распространенных неврологических расстройств [5]. В настоящее время всё более актуальным становится исследование когнитивных функций. Подтверждением это- 
му служат большое количество работ и большая глубина исследований в области когнитивной психологии [13].

Когнитивные изменения вносят значительный вклад в клиническую картину РС, они могут серьезно нарушать многие виды ежедневной активности, снижать качество жизни пациентов, затруднять адаптацию к хроническому заболеванию, процесс реабилитации [21]. Ранняя инвалидизация больных РС обусловлена зачастую не только неврологическим, но и когнитивным дефицитом.

В настоящее время отношение к когнитивным нарушениям, как проявлениям демиелинизирующего и нейродегенеративного процессов при РС существенно изменилось, их считают одними из основных клинических проявлений РС [10, 23].

Цель исследования: выявление когнитивных нарушений при рассеянным склерозе.

\section{Материалы и методы}

В обследовании принимали участие больнее РС, обследовано 20 больных на базе кафедры неврологии психиатрии и психологии Южно Казахстанской Государственной Фармацевтической Академии.

Диагноз РС устанавливался в соответствии с клиническими критериями. Инструментальное обследование включало УЗДГ, ЭЭГ, РЭГ, обследование глазного дна, которые проходили все обследованные, использовался метод КТ.

У больных будет исследоваться когнитивные изменения при помощи шкалы оценки психического статуса (Mini-Mental State Examenation (MMSE)) [25]. Относится к наиболее распространенным в настоящее время тестам, предназначенным для скрининг-исследования когнитивных функций (Folstein M.F. и соавт., 1975) [25].

\section{Результаты и обсуждения:}

У обследованных пациентов ремиттирующий тип течения заболевания наблюдался у 14 человек (72\% случаев), вторично-прогрессирующий - у 6 пациентов (28\% случаев). Наиболее частыми клиническими проявлениями в нашем исследовании являлись двигательные $(67,2 \%$ всех случаев), чувствительные $(58,6 \%)$ и координаторные нарушения (57,5\%). Высокая частота встречаемости этих расстройств при РС позволяет традиционно относить их к наиболее типичным симптомам заболевания. Тазовые расстройства отмечены в $53,3 \%$ случае в, стволовые нарушения в $23,1 \%$. По сравнению с ремиттирующим РС среди больных с вторично-прогрессирующим РС четко прослеживается увеличение частоты расстройств, причем преимущественно за счет грубой неврологической симптоматики.

В целом в группе больных РС когнитивный дефицит отмечался в 74,8\% случаев. Когнитивные нарушения наблюдались у 64,8\% больных.

Степень нарушения когнитивных функций по результатам краткой шкалы оценки психического статуса (MMSE) при разных типах течения (ВПРС, РРС), 74\% случаев.

\section{— Когнетивные нарушения при ВПРС घеменция легкой степени при ВПРС \\ ПУмереннаядеменция при ВПРС ФКогнетивные нарушения при РРС \\ $\square$ Деменция легкой степени при РPC Умереннаядеменция при РPC}

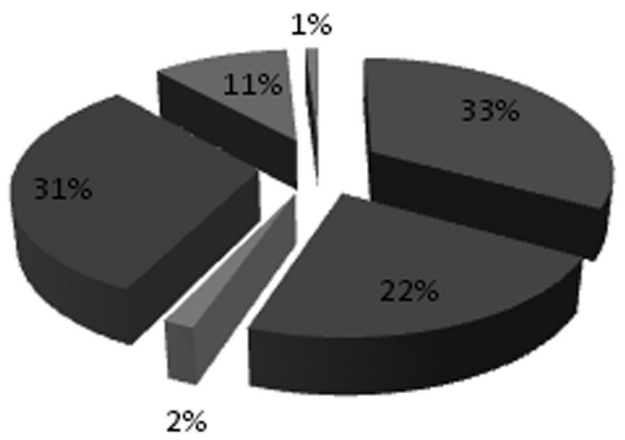

Рис.1 Сравнительный анализ когнетивных нарушений\% 
После разделения всех больных на подгруппы в зависимости от типа течения более грубые нарушения показаны при вторичном прогрессировании заболевания. Анализ данных MMSE у пациентов с РС выявил ряд отличий в структуре когнитивных нарушений. В большей степени нарушались такие функции, как слухоречевая память, способность к обратному счету. При этом такие проявления, как ориентация в пространстве и времени, экспрессивная и импрессивная речь, копирование пятиугольников в общем не характерны для РС.

Выводы. Во всех группах больных РС отмечаются когнетивные нарушения. В целом в

\section{СПИСОК ЛИТЕРАТУРЫ}

1. Атрошенкова А.А. Клинико-эпидемиологическая характеристика рассеянного склероза в Томской области: автореф. дис. ... канд. мед. наук. Новосибирск, 2004.-17с.

2. Бойко А.Н., Хачанова Н.В., Буглан А.В. Возможность использования клинических, генетических показателей и данных магнитно-резонансной томографии для прогнозирования эффектов лечения бета-интерфероном-1 в рассеянного склероза // Журнал неврологии и психиатрии им. С.С. Корсакова. 2000. № 12. С. 53-59.

3. Гусев Е.И., Демина Т.Л., Бойко А.Н. Рассеянный склероз. М.: Нефть и газ, 1997. 463 с.

4. Гусев Е.И. Лечение рассеянного склероза // Лечение нервных болезней. 2005. С. 1-8.

5. Захаров В.В., Яхно Н.Н. Когнитивные расстройства в пожилом и старческом возрасте: методическое пособие для врачей. М., 2005. 72 с.

6. Иммунологические исследования в диагностике рассеянного склероза / И.Г. Никифорова [и др.] // Неврологический журнал. 2003. №5. С. 9-14.

7. Использование глатирамера ацетата (копаксона) в лечении больных рассеянным склерозом. Опыт Московского центра рассеянного склероза / Т.Л. Демина [и др.] // Журнал неврологии и психиатрии им. С.С. Корсакова. Рассеянный склероз: прил. к журн. 2003. № 2. С. 91-97.

8. Киричук В.Ф., Стрекнев А.Г. Роль системы гемостаза в патогенезе и течении рассеянного склероза // Журнал неврологии и психиатрии им. С.С. Корсакова. Рассеянный склероз: прил. к журн. 2003. №2. C. 34-38.

9. МакДональд В.Я., Фазекас Ф., Томпсон А.Д. Диагностика рассеянного склероза // Журнал неврологии и психиатрии им. С.С. Корсакова. Рассе- группе больных РС когнитивный дефицит отмечался в 74,8\% случаев. Когнитивные нарушения наблюдались у 64,8\% больных.

Когнитивный дефицит при РС характеризуется нарушением скорости обработки информации, кратковременной памяти, концентрации внимания, исполнительных функций, речи, в меньшей степени нарушением зрительно-пространственных способностей.

Когнитивные нарушения при РС носят прогрессирующий характер. Прогрессирование отмечается преимущественно за счёт нарастания выраженности дизрегуляторных и нейродинамических расстройств.

янный склероз: прил. к журн. 2003. № 2. С. 4-9. 10. Механизмы развития нейродегенеративного процесса при рассеянном склерозе - нейропротективное влияние препаратов р-интерферона сегодня и нейротрофические факторы завтра / А.Н. Бойко [и др.] // Журнал неврологии и психиатрии им. С.С. Корсакова. Рассеянный склероз: прил. к журн. 2003. №2. С.83-90.

11. Нейротрансмиттерные механизмы двигательных нарушений при рассеянном склерозе / В.П. Бархатова [и др.] // Журнал неврологии и психиатрии им. С.С. Корсакова. 2007. №2. С. 43-48.

12. Рассеянный склероз. Избранные вопросы теории и практики / Под ред. И.А. Завалишина, В.И. Головкина. М.: Медицина, 2000.- 640 с.

13. Солсо Р.Л. Когнитивная психология: пер. с англ. М.: Тривола, Либерия, 2002. - 600 с.

14. Современная диагностика рассеянного склероза / Н.М. Жулев [и др.] Спб.: МАЛО, 1998.-28 с. 15. Тотолян Н.А., Трофимова Т.Н., Скоромец А.А. Возможности метода магнитно-резонансной визуализации в диагностике рассеянного склероза // Журнал неврологии и психиатрии им. С.С. Корсакова. Рассеянный склероз: прил. к журн. 2002. №5 . C. 32-41.

16. Хондкариан О.А., Завалишин И.А., Невская О.М. Рассеянный склероз. М.: Медицина, 1987. -253 с.

17. Черниговская Н.В. О патогенезе рассеянного склероза. М.: Медицина, 1987.- 376 с.

18. Шмидт Т.Е. Международный симпозиум "Бетаферон в лечении рассеянного склероза" (Берлин, 4 марта 2000 г.) // Неврологический журнал. 2000. №5. C. 56-61.

19. Шмидт Т.Е. Патогенез, лечение и ведение больных рассеянным склерозом. По материалам 
6-го конгресса Европейской федерации неврологических обществ, Вена, 2002 г., и конференции "Программа поддержки больных рассеянным склерозом", Севилья, 2003 г. // Неврологический журнал. 2003. №3. С. 46-50.

20. Cytoxic $\mathrm{T}$ lymphocytes in autoimmune and degenerative CNS diseases / H. Neumann [et al.] II Trends in Neurisienses. 2002. V. 25. №6. P. 313-319. 21. Cognitive disturbances in patients with relapsing remitting multiple sclerosis / W.W. Beatty [et al.] //Archives of Neurology. 1989. V. 46. P. 1113-1119. 22. Molecular mimicry and multiple sclerosis: degenerate T-cell recognition and the induction of autoim- munity / B. Gran [et al.] II Annals of Neurology. 1999. V.45. P. 559-557.

23. Nocentini U., Pasqualetti P., Bonavita S. Cognitive dysfunction in patients with relapsingremitting multiple sclerosis II Multiple Sclerosis. 2006. V. 12. P. 77-87.

24. Smith K.J., Kapoor R., Felts P.A. Demyelization: the role of reactive oxygen and nitrogen species II Brain Pathol. 1999. V. 9. P. 69-92.

25. Folstein M.F., Folstein S.E., McHugh P.R. MiniMental State - A practical method for grading the cognitive state of patients for the clinical II J. Psychiatr. Res. 1975. V. 12. P. 189-198.

\title{
SUMMARY
}

\section{COGNITIVE AND PSYCHOLOGICAL ASPECTS OF MULTIPLE SCLEROSIS}

\author{
G.A.Duschanova, E.T.Zulfikarova, S.A.Chumakov \\ South Kazakhstan State Pharmaceutical Academy, Shymkent, Kazakhstan
}

Multiple sclerosis disease affecting young adults and leads to disability. There were 20 patients with multiple sclerosis at the Department of Psychiatry, Neurology and Psychology of the South Kazakhstan State Pharmaceutical Academy. In order to detect cognitive impairment and psychological aspects. In all groups of patients with multiple sclerosis are marked cognitive violations, the deficit was observed in $74.8 \%$ of cases. Cognitive deficits in the multiple sclerosis is characterized by impaired information processing speed, shortterm memory, concentration, attention, executive function, speech, to a lesser extent against the visual-spatial abilities. Cognitive impairment in multiple sclerosis are progressive in nature. The progression is marked primarily by growth neural disorders.

\section{XÜLASə}

\section{DAĞINIQ SKLEROZUN KOQNITIV VӘ PSIXOLOJİ ASPEKTLӘRI}

\author{
Q.A.Duşanova, E.T.Zulfiqarova, S.A.Çumakov \\ Cənub-Kazaxıstan Dövlət Farmosevtik akademiyası, Şimkent, Kazaxıstan
}

Dağınıq skleroz cavan yaşda rast gəlinən və əlilliyə gətirib çıxaran xəstəlikdlir. Cənub-Kazaxıstan Dövlət Farmosevtik akademiyasının nevrologiya, psixiatriya və psixologiya kafedrasının bazasında 20 dağınıq sklerozlu xəstə müayinə olunmuşdur. Məqsəd koqnitiv pozulmalar və psixoloji aspektlərin öyrənilməsi olmuşdur. Dağ1nıq sklerozlu xəstələr olan bütün qruplarda koqnitiv pozulmalar, defisit $(74,8 \%)$ qeydə alınmışdır. Dağınıq skleroz zamanı koqnitiv defisit informasiyanın dərkedilmə sürətinin, qısamüddətli yaddaşın, diqqətin konsentrasiyasının, icraedici funksiyaların, nitqin pozulması ilə, az hallarda görmə-sahə funksiyasının pozulması ilə xarakterizə olunur. Dağınıq skleroz zamanı koqnitiv pozulmalar proqressivləşən xarakter daşıyır. Proqressivləşmə əsas etibarı ilə dizrequlyator və neyrodinamik pozulmaların artması hesabına baş verir.

Redaksiyaya daxil olub: 03.08.2013

Çapa tövsiya olunub: 29.08.2013

Rəyçi: Z.M.Sadıxova, t.ü.f.d., dosent 